ROCZNIKI NAUK PRAWNYCH

Tom XXXI, numer $1-2021$

DOI: https://doi.org/10.18290/rnp21311-2

\title{
ZWOLNIENIE ZE SŁUŻBY W POLICJI NA PODSTAWIE ART. 41 UST. 2 PKT 4 USTAWY O POLICJI W ZWIĄZKU Z NABYCIEM PRZEZ FUNKCJONARIUSZA PRAWA DO EMERYTURY
}

\begin{abstract}
WSTĘP
Specyficzny charakter służby publicznej zdeterminował ustawodawcę do wyodrębnienia stosunku służbowego spośród innych stosunków prawnych i ukształtowania go w szczególny sposób ${ }^{1}$. Podstawą zatrudnienia funkcjonariusza Policji (a także funkcjonariuszy innych służb zmilitaryzowanych i paramilitarnych) jest bowiem stosunek służbowy powstający w drodze mianowania. Wynika to wprost $\mathrm{z}$ art. 28 ust. 1 ustawy z dnia 6 kwietnia $1990 \mathrm{r}$. o Policji². Ma on, co należy podkreślić, charakter wyłącznie administracyjnoprawny ${ }^{3}$. Jest formą niepracowniczego zatrudnienia ${ }^{4}$. I chociaż nazwa tego

Dr PAWEŁ GACEK - Komenda Główna Policji; e-mail: p.gacek@wp.pl; ORCID: https://orcid.org/ 0000-0001-6365-3146.

${ }^{1}$ Szerzej na temat stosunku służbowego zob. T. KUCZYŃSKI, E. MAZURCZAK-JASIŃSKA, J. StelinA, Stosunek stużbowy, [w:] System prawa administracyjnego, t. XI, red. R. Hauser, Z. Niewiadomski, A. Wróbel, Warszawa: C.H. Beck 2011; P. SzUSTAKIEWICZ, Stosunki stużbowe funkcjonariuszy stużb mundurowych i żotnierzy zawodowych jako sprawa administracyjna, Warszawa: Difin S.A. 2012; M. WIECZOREK, Charakter prawny stosunków stużbowych funkcjonariuszy stużb mundurowych, Toruń: Wydawnictwo Adam Marszałek 2017, a także P. GACEK, Nawiazanie stosunku stużbowego z funkcjonariuszem Policji, „Administracja Teoria Dydaktyka Praktyka” 2011, nr 2 (23), s. 68-93.

${ }^{2}$ Ustawa z dnia 6 kwietnia 1990 r. o Policji, Dz.U. z 2020 r., poz. 360 z późn. zm.

${ }^{3}$ A. Michalek, Komentarz do art. 28, [w:] Ł. CZebotar, Z. GĄDZiK, A. ŁyżWA, A. Michalek, A. ŚwierczewsKa-GąSIORowsKa, M. ToKARSKi, Ustawa o Policji. Komentarz, Warszawa: Wolters Kluwer 2015, s. 366; P. GACEK, Nawiazanie, s. 76; P. GACEK, Odwołanie od rozkazu personalnego, „Przegląd Policyjny” 2016, nr 3 (123), s. 80; M. TANIEwsKA, Stosunek stużbowy funkcjonariuszy Policji, Urzędu Ochrony Państwa i Straży Granicznej, [w:] Prawo policyjne. Komentarz, red.
\end{abstract}


stosunku „mianowanie” jest tożsama z tą, która została zamieszczona w art. 76 ustawy z dnia 26 czerwca 1974 r. kodeks pracy ${ }^{5}$, to nie budzi wątpliwości, że są to dwie odrębne i różniące się od siebie konstrukcje prawne ${ }^{6}$. W przypad$\mathrm{ku}$, o którym mowa $\mathrm{w}$ przepisach prawa pracy, podstawą zatrudniania $\mathrm{z}$ mianowania jest stosunek pracy; tzw. służbowy stosunek pracy. Elementu tego pozbawiony jest stosunek służbowy funkcjonariuszy służb zmilitaryzowanych, w tym Policji ${ }^{7}$. Tym samym stosunek ten nie jest usytuowany w obszarze gałęzi prawa, jaką stanowi prawo pracy, ale wyłącznie w obrębie prawa administracyjnego. Jak słusznie zauważa T. Zieliński, kryterium odgraniczającym stosunek służbowy od stosunku pracy jest tzw. pełna dyspozycyjność. Nasilenie w nim pierwiastków władczych jest tak duże, że reżim prawa pracy musi ustąpić przepisom prawa administracyjnego ${ }^{8}$. Przepisy wymienione jako pierwsze byłyby mało przydatne ${ }^{9}$, a tym samym nieefektywne w tym zakresie.

Nawiązanie, zmiana, a także rozwiązanie stosunku służbowego następuje natomiast $\mathrm{w}$ drodze kwalifikowanego aktu administracyjnego, jakim jest decyzja administracyjna (rozkaz personalny). Treść stosunku służbowego nie może być zatem w sposób dowolny modyfikowana, ale wyłącznie w sposób przewidziany przez przepisy pragmatyki służbowej. Twierdzenie to odnosi się także do kwestii zwolnienia ze służby. Pragmatyka służbowa przewiduje bowiem zamknięty katalog podstaw zwolnienia ze służby w Policji (numerus clausus). Zostały one zamieszczone w art. 41 ust. 1-3, a także w art. 38 ust. 4 ustawy o Policji, jako obligatoryjne (art. 41 ust. 1 pkt 1-7, a także w art. 41 ust. 3 ustawy o Policji) oraz fakultatywne (art. 41 ust. 2 pkt 1-9, a także

S. Sagan, Katowice: POLBOD 1992, s. 69; W. KotowsKi, Ustawa o Policji. Komentarz, Warszawa: Wolters Kluwer 2008, s. 380-381.

${ }^{4}$ T. KUCZYŃSKI, Wybrane problemy orzecznictwa sadowoadministracyjnego $w$ sprawach z zakresu stosunków stużbowych, „Zeszyty Naukowe Sądownictwa Administracyjnego” 2010, nr 5-6 (32-33), s. 249.

${ }^{5}$ Ustawa z dnia 26 czerwca 1974 r. - Kodeks pracy, Dz.U. z 2020 r., poz. 1320 z późn. zm.

${ }^{6}$ P. Konus, Komentarz do art. 2, [w:] Kodeks pracy. Komentarz, red. A. Sobczyk, Legalis, teza 5.

${ }^{7}$ „Wydaje się, że możliwe jest również inne uzasadnienie «wyłączenia» funkcjonariuszy z zakresu definicji stosunku pracy [...]. Funkcjonariusze działają bowiem nie tyle w interesie pracodawcy, ile wykonują powierzone im czynności w celu zapewnienia ładu, porządku i bezpieczeństwa publicznego - nie tyle zatem pracują, ile służą" (P. Korus, Komentarz do art. 2, teza 5 i tam powołany wyrok Sądu Najwyższego z dnia 1 października 1977 r., I CR 530/77, niepubl.).

${ }^{8}$ T. ZIELIŃSKI, Stosunek prawa pracy do prawa administracyjnego, Warszawa: Wydawnictwo PWN 1977, s. 181.

${ }^{9}$ Uchwała Sądu Najwyższego - Izba Administracyjna, Pracy i Ubezpieczeń Społecznych z dnia 5 grudnia 1991 r., I PZP 60/91, Legalis nr 27539. 
w art. 38 ust. 4 ustawy o Policji) podstawy zwolnienia ze służby w Policji. Zwolnienie zatem na innej podstawie niezamieszczonej w ustawie o Policji skutkowałoby wydaniem decyzji obarczonej wadą kwalifikowaną, co z kolei obligowałoby do wyeliminowania jej z obrotu prawnego przez stwierdzenie jej nieważności na mocy art. $156 \S 1$ pkt 2 k.p.a. ${ }^{10}$ Należy zgodzić się ze stanowiskiem zaprezentowanym w doktrynie, z którego wynika, że:

Precyzyjne określenie przesłanek rozwiązania stosunku służbowego policjanta ma charakter gwarancyjny $\mathrm{w}$ stosunku do samych funkcjonariuszy, ponieważ chroni ich przed nieuzasadnionym, arbitralnym zwolnieniem. Przełożeni są w tej materii związani przepisami ustawy o Policji i nie mogą działać tylko na podstawie swojej woli. Takie rozwiązanie sprzyja stabilności i jakości służby funkcjonariuszy, którzy mogą skoncentrować się na wykonywaniu zadań, a nie zabezpieczeniu bytu swojego i rodziny w razie niespodziewanego i nieuzasadnionego zwolnienia ${ }^{11}$.

Każda z podstaw zwolnienia ze służby w Policji jest odrębna i niekonkurencyjna $\mathrm{w}$ stosunku do pozostałych. Każda też odrębnie określa przesłanki, których zmaterializowanie się obliguje albo też uprawnia właściwego przełożonego do wydania decyzji w przedmiocie zwolnienia funkcjonariusza ze służby w Policji. Każda ze wskazanych podstaw zwolnienia ze służby w Policji wytycza także odrębne granice sprawy administracyjnej w rozumieniu art. 1 k.p.a. To z kolei determinuje organ do podjęcia w ramach danego postępowania administracyjnego określonych czynności, relewantnych dla jego przedmiotu, które pozwolą na urzeczywistnienie jego celu, tj. potwierdzenie, że zmaterializowała się lub zmaterializowały się określone przesłanki objęte konkretną podstawą zwolnieniową, a tym samym, że możliwe jest wydanie rozstrzygnięcia o charakterze merytorycznym - decyzji administracyjnej zwalniającej policjanta ze służby w Policji.

Wybrane podstawy zwolnienia ze służby były już uprzednio przedmiotem szerszej analizy ${ }^{12}$, jednakże niniejsze opracowanie nie dotyczy tych kwestii.

${ }^{10}$ Ustawa z dnia 14 czerwca 1960 r. - Kodeks postępowania administracyjnego, Dz.U. z 2021 r., poz. $735 \mathrm{z}$ późn. zm. [dalej: k.p.a.]

${ }^{11}$ B. Opaliński, Komentarz do art. 41, [w:] B. OpAlińsKi, M. Rogalski, P. SzustakiewiCz, Ustawa o Policji. Komentarz, Legalis, teza 2.

${ }^{12}$ Zob. P. GACEK, Orzeczenie o trwatej niezdolności do stużby jako podstawa obligatoryjnego zwolnienia ze stużby w Policji, „Przegląd Policyjny” 2020, nr 2 (138), s. 121-146; TENŻE, Zwolnienie ze stużby $w$ Policji na podstawie art. 41 ust. 2 pkt 5 ustawy o Policji a prawo policjanta do nagrody rocznej, „Roczniki Nauk Prawnych” 29(2019), nr 4, s. 201-221; TENŻE, Opinia organizacji zakładowej zwiąku zawodowego policjantów w sprawie zwolnienia ze stużby w Policji 
Uwaga zostanie skoncentrowana wyłącznie na jednej fakultatywnej podstawie zwolnienia ze służby określonej w art. 41 ust. 2 pkt 4 ustawy o Policji. Omówiona zostanie przesłanka, która materializuje uprawnienie przełożonego właściwego $\mathrm{w}$ sprawach osobowych do zastosowania tej podstawy zwolnienia ze służby. Istotne jest również to, że wymieniony przepis art. 41 ust. 2 pkt 4 ustawy o Policji warunkuje zwolnienie policjanta od faktu nabycia przez niego prawa do emerytury z tytułu osiągnięcia 30 lat wysługi emerytalnej. Jednak analiza kwestii, czy zwolnienie na tej podstawie nie jest przejawem nierównego i dyskryminującego traktowania funkcjonariusza $z$ uwagi na osiągnięty wiek, przekracza ramy przedmiotowego opracowania.

\section{PRZESŁANKA WARUNKUJĄCA ZWOLNIENIE POLICJANTA ZE SŁUŻBY NA PODSTAWIE ART. 41 UST. 2 PKT 4 USTAWY O POLICJI}

Decyzja o zwolnieniu na podstawie art. 41 ust. 2 pkt 4 ustawy o Policji jest decyzją uznaniową ${ }^{13}$. Z przepisu tego wynika, że policjant może zostać zwolniony ze służby $\mathrm{w}$ Policji w przypadku nabycia prawa do emerytury $z$ tytułu osiągnięcia 30 lat wysługi emerytalnej ${ }^{14}$. I to jest jedyną przesłanką, która warunkuje zastosowanie tej podstawy zwolnienia ze służby ${ }^{15}$. Omawiany przepis nie wskazuje bowiem innych - dodatkowych kryteriów, których zaistnienie warunkowałoby zastosowanie tego przepisu ${ }^{16}$. Wynika $\mathrm{z}$ tego, że przesłanka objęta przepisem art. 41 ust. 2 pkt 4 ustawy o Policji została w sposób wyczerpujący sprecyzowana w jego treści. Oznacza to również, że brak jest podstaw do tworzenia dodatkowych wymogów, których spełnienie

(art. 43 ust. 3 ustawy o Policji), „Policja. Kwartalnik Kadry Kierowniczej Policji” 2018, nr 2, s. 26-37; TENŻE, Zwolnienie ze służby $w$ Policji $w$ zwiąku ze złożonym przez policjanta pisemnym zgłoszeniem o wystapieniu z niej na podstawie art. 41 ust. 3 ustawy z dnia 6 kwietnia 1990 o Policji, „Przegląd Policyjny” 2018, nr 2 (130), s. 63-91; TENŻE, Zmiana stadium postępowania karnego jako podstawa do zwolnienia policjanta ze stużby w Policji ze względu na ,ważny interes stużby”, „Przegląd Policyjny” 2017, nr 4 (128), s. 70-99.

${ }^{13}$ Wyrok Wojewódzkiego Sądu Administracyjnego w Warszawie z dnia 28 czerwca 2010 r., II SA/Wa 401/10, Legalis nr 253011.

${ }^{14}$ Wyrok Naczelnego Sądu Administracyjnego z dnia 9 maja 2012 r., I OSK 1840/11, Legalis nr 778645.

${ }^{15}$ Wyrok Naczelnego Sądu Administracyjnego z dnia 16 października 2009 r., I OSK 174/09, Legalis nr 212998, wyrok Wojewódzkiego Sądu Administracyjnego w Warszawie z dnia 10 sierpnia 2018 r., II SA/Wa 2131/17, Legalis nr 2300580.

${ }^{16}$ Wyrok Wojewódzkiego Sądu Administracyjnego w Warszawie z dnia 10 lutego 2009 r., II SA/Wa 1264/08, Legalis nr 183469. 
umożliwia zastosowanie tej podstawy zwolnienia ze służby w Policji. Uzależnienie decyzji od takich dodatkowych kryteriów świadczyłoby bowiem o wykroczeniu przez organ poza granice tej konkretnej sprawy administracyjnej, w rozumieniu art. 1 k.p.a., co z kolei prowadziłoby do wydania rozstrzygnięcia nie powołując się na art. 41 ust. 2 pkt 4 ustawy o Policji, lecz na podstawie przesłanki objętej art. 41 ust. 2 pkt 4 ustawy o Policji oraz innej zawartej w art. 41 ust. 1-3 albo w art. 38 ust. 4 tej ustawy bądź też nieznanej pragmatyce służbowej. Nie ma jednak jednej sprawy administracyjnej. Każda z podstaw zwolnienia ze służby w Policji wytycza odrębne granice sprawy administracyjnej, która raz wskazana przez organ administracyjny inicjujący dane postępowanie w sprawie zwolnienia ze służby, nie może być zmieniana lub modyfikowana $\mathrm{w}$ jego toku. Wydanie rozstrzygnięcia $\mathrm{z}$ naruszeniem granic sprawy administracyjnej będącej powodem wszczęcia postępowania w sprawie zwolnienia ze służby, stanowiłoby o wadzie kwalifikowanej takiej decyzji jako wydanej albo bez podstawy prawnej, albo z rażącym naruszeniem prawa, co w konsekwencji musiałoby skutkować koniecznością stwierdzenia jej nieważności zgodnie z art. $156 \S 1$ pkt 2 k.p.a.

Jest to o tyle istotne, że organy administracyjne zobligowane są na mocy art. 7 Konstytucji Rzeczypospolitej z dnia 2 kwietnia 1997 r. ${ }^{17}$ do działania zgodnie z prawem i obowiązującymi przepisami prawa. Zasada ta została również powtórzona $\mathrm{w}$ przepisach procedury administracyjnej $\mathrm{w}$ art. $6 \mathrm{i}$ art. 7 k.p.a. ${ }^{18}$ Obliguje to więc organ do zbierania wyłącznie materiału dowodowego i dokonywania takich ustaleń, które pozwalają na urzeczywistnienie celu postępowania administracyjnego, a zatem czynności relewantnych dla jego przedmiotu, tj. tych, które mieszczą się w granicach konkretnej sprawy administracyjnej.

$\mathrm{W}$ postępowaniu administracyjnym $\mathrm{w}$ sprawie zwolnienia na podstawie art. 41 ust. 2 pkt 4 ustawy o Policji organ administracyjny ustalając, czy zaistniała przesłanka do zwolnienia na wymienionej podstawie, zobowiązany jest do ukierunkowania czynności wyłącznie w celu ustalenia, czy policjant nabył prawo do emerytury z tytułu osiągnięcia 30 lat wysługi emerytalnej. Zasady, na jakich funkcjonariusze służb mundurowych, w tym Policji, nabywają prawo do emerytury, zostały szczegółowo określone w ustawie z dnia 18 lutego 1994 r. o zaopatrzeniu emerytalnym funkcjonariuszy Policji, Agen-

\footnotetext{
${ }^{17}$ Konstytucja Rzeczypospolitej z dnia 2 kwietnia 1997 r., Dz.U. z 1997 r., Nr 78, poz. 483 z późn. zm.

${ }^{18}$ Wyrok Naczelnego Sądu Administracyjnego z dnia 26 października 2016 r., II OSK 132/15, Legalis nr 1554129.
} 
cji Bezpieczeństwa Wewnętrznego, Agencji Wywiadu, Służby Kontrwywiadu Wojskowego, Służby Wywiadu Wojskowego, Centralnego Biura Antykorupcyjnego, Straży Granicznej, Straży Marszałkowskiej, Służby Ochrony Państwa, Państwowej Straży Pożarnej, Służby Celno-Skarbowej i Służby Więziennej oraz ich rodzin ${ }^{19}$. Warto także zaznaczyć, że zgodnie z art. 12 ust. 1 tej ustawy emerytura policyjna przysługuje funkcjonariuszowi zwolnionemu ze służby, który w dniu zwolnienia posiada co najmniej 15 lat służby w Policji, natomiast zgodnie $\mathrm{z}$ art. $18 \mathrm{~b}$ ust. 1 tej ustawy funkcjonariuszowi przyjętemu po raz pierwszy po dniu 31 grudnia 2012 r. do służby w Policji emerytura przysługuje, jeśli $\mathrm{w}$ dniu zwolnienia posiada on co najmniej 25 lat służby. Przesłanka, o której mowa w art. 41 ust. 2 pkt 4 ustawy o Policji, nie materializuje się wobec tego z chwilą, gdy policjant nabywa prawo do emerytury. Nabycie prawa do emerytury jest tylko warunkiem koniecznym (lecz niewystarczającym) do zwolnienia ze służby na podstawie art. 41 ust. 2 pkt 4 ustawy o Policji. Niezbędne jest również, aby nabycie przez niego tego prawa nastąpiło z tytułu osiągnięcia 30 lat wysługi emerytalnej. Problematyka zasad obliczania wysługi emerytalnej przekracza zakres przedmiotowego opracowania.

$\mathrm{Na}$ marginesie dodać również należy, że zgodnie z art. 43 ust. 1 ustawy o Policji zwolnienie policjanta ze służby na podstawie art. 38 ust. 4 oraz art. 41 ust. 1 pkt 1 i 2 oraz ust. 2 pkt 1, 4, i 6 tej ustawy nie może nastąpić przed upływem dwunastu miesięcy od dnia zaprzestania służby z powodu choroby, chyba że policjant zgłosi pisemnie wystąpienie ze służby. Zaznaczenia jednak wymaga, że warunek wynikający z powołanego przepisu nie odnosi się do przesłanki warunkującej zastosowanie wskazanej w nim jednej z podstaw zwolnienia ze służby w Policji, w tym art. 41 ust. 2 pkt 4 ustawy o Policji. Dotyczy on bowiem wyłącznie terminu, w którym dopuszczalne jest takie zwolnienie, jeśli zrealizowała się przesłanka lub przesłanki wskazane w poszczególnych podstawach zwolnieniowych enumeratywnie wyliczonych w art. 43 ust. 1 ustawy o Policji. Przenosząc te rozważania na grunt omawianej problematyki należy stwierdzić, że kwestia terminu zwolnienia ze służby w Policji może być przedmiotem ustaleń organu administracyjnego wyłącznie w sytuacji, gdy stwierdzi on w sposób niebudzący wątpliwości, że zaist-

\footnotetext{
${ }^{19}$ Ustawa z dnia 18 lutego 1994 r. o zaopatrzeniu emerytalnym funkcjonariuszy Policji, Agencji Bezpieczeństwa Wewnętrznego, Agencji Wywiadu, Służby Kontrwywiadu Wojskowego, Służby Wywiadu Wojskowego, Centralnego Biura Antykorupcyjnego, Straży Granicznej, Straży Marszałkowskiej, Służby Ochrony Państwa, Państwowej Straży Pożarnej, Służby Celno-Skarbowej i Służby Więziennej oraz ich rodzin, Dz.U. z 2020 r., poz. 723.
} 
niała przesłanka wynikająca z przepisu art. 41 ust. 2 pkt 4 ustawy o Policji. Ustalenie negatywne $\mathrm{w}$ tym zakresie czyni bezprzedmiotowym rozstrzyganie o terminie zwolnienia, które nie może nastąpić wobec braku podstaw do wydania decyzji o zwolnieniu zgodnie z art. 41 ust. 2 pkt 4 ustawy o Policji.

\section{GRANICE UZNANIA ADMINISTRACYJNEGO W KONTEKŚCIE ZWOLNIENIA ZE SŁUŻBY NA PODSTAWIE ART. 41 UST. 2 PKT 4 USTAWY O POLICJI}

Jak już wcześniej zaznaczono, zwolnienie ze służby na podstawie art. 41 ust. 2 pkt 4 ustawy o Policji ma charakter uznaniowy. Oznacza to konieczność każdoczesnego zbadania, czy organ administracyjny podejmując decyzje o zwolnieniu funkcjonariusza uwzględnił zarówno interes społeczny, który w tym przypadku konkretyzuje się w pojęciu „interes służby” lub „dobro służby", jak i słuszny interes strony. Nie obliguje to jednak do automatycznego zrównoważenia tych dóbr w sytuacji oczywistej kolizji pomiędzy nimi. W takich sytuacjach organ zobowiązany jest do wykazania przyczyn, dla których jednej wartości dał prymat w stosunku do drugiej. Jak słusznie zauważa M. Nowikowska, ,[...] obowiązkiem organu Policji jest rozważenie, czy dobro służby przemawia za zwolnieniem Policjanta ze służby, czy też pomimo posiadania 30-letniej wysługi zasadnym byłoby umożliwienie dalszego pełnienia służby"20.

Nie ulega wątpliwości, że interes policjanta w dalszym zatrudnieniu sprowadza się do tego, że pozwala na stabilizację w odniesieniu do jego sytuacji socjalno-bytowej, z uwagi na gwarancję otrzymywania uposażenia i innych świadczeń związanych z pełnioną służbą na dotychczasowym poziomie, $\mathrm{tj}$. w wymiarze wyższym od tych, które przysługiwałyby mu z tytułu pobieranego świadczenia emerytalnego, a także możliwość dalszej samorealizacji, doskonalenia własnych umiejętności i sukcesywnego podnoszenia kwalifikacji zawodowych.

Z kolei w interesie służby należałoby ustalić, czy dalsze kontynuowanie stosunku służbowego $\mathrm{z}$ funkcjonariuszem jest zasadne $\mathrm{z}$ punktu widzenia

\footnotetext{
${ }^{20}$ M. Nowikowska, Komentarz do art. 41, [w:] Ustawa o Policji. Komentarz, red. K. Chałubińska-Jentkiewicz, J. Kurek, Legalis, teza 14 - i tam powołany wyrok Wojewódzkiego Sądu Administracyjnego w Poznaniu z dnia 18 stycznia 2018 r., IV SA/Po 960/17, Legalis nr 1741128, a także wyrok Wojewódzkiego Sądu Administracyjnego w Warszawie z dnia 11 grudnia 2018 r., II SA/Wa 2133/17, Legalis nr 1974446.
} 
możliwości szybkiego, sprawnego i efektywnego wykonywania ustawowych zadań nałożonych na tę formację, a zatem czy zasadne jest zatrudnienie policjanta, który nabył prawo do emerytury z tytułu osiągnięcia 30 lat wysługi emerytalnej w kontekście efektywnej realizacji misji tej organizacji.

Odpowiedź w tym zakresie wymaga odniesienia się do treści art. 1 ust. 1 ustawy o Policji, zgodnie z którym Policja stanowi umundurowaną i uzbrojoną formację służącą społeczeństwu i przeznaczoną do ochrony bezpieczeństwa ludzi oraz utrzymywania bezpieczeństwa i porządku publicznego. Podstawowym warunkiem, który umożliwia wykonanie tych zadań, jest zapewnienie zatrudnienia dla rzeczywistych wykonawców, tj. funkcjonariuszy w ramach stosunku służbowego. Jednym z najważniejszych i charakterystycznych cech tego stosunku jest dyspozycyjność, zdyscyplinowanie i podporządkowanie funkcjonariuszy w służbie. Granice tej dyspozycyjności określają przepisy pragmatyki służbowej zawarte zarówno w ustawie o Policji, jak i w przepisach do niej wykonawczych. Są one, jak wskazuje $\mathrm{SN}^{21}$, jednym z głównych warunków wykonania tych zadań Policji. Stosunek służbowy nie może być zatem traktowany jako zwykła praca najemna. Nieprzypadkowo ten rodzaj więzi prawnej został potraktowany w sposób odrębny od innych form zatrudnienia. Stosunek ten pełni szczególną funkcję, bo powinien stworzyć warunki dla wykonania nałożonych na poszczególnych funkcjonariuszy zadań, których suma w szerszym aspekcie ma stanowić świadectwo dążenia do realizacji zadań całej formacji. Tym samym nie ma ona charakteru wyłącznie socjalnego. Przeciwne stanowisko nie wytrzymuje krytyki, bo sprowadzałoby Policję do organizacji utworzonej w celu zatrudnienia funkcjonariuszy. W rzeczywistości to zatrudnienie członków tej formacji ma umożliwiać realizację zadań Policji.

Osobami odpowiedzialnymi za kształtowanie polityki kadrowej w poszczególnych jednostkach organizacyjnych Policji są jej kierownicy, będący jednocześnie przełożonymi właściwymi w sprawach osobowych policjantów pełniących służbę w tych jednostkach. Są oni kompetentni do swobodnego kształtowania struktury zatrudnienia w tych jednostkach, bowiem mają najpełniejszą wiedzę zarówno o posiadanym zasobie kadrowym, jak i o realnych potrzebach służby, tj. o potrzebach związanych z koniecznością skutecznej i efektywnej realizacji zadań tych jednostek Policji. Przełożeni ci zobligowani są wobec tego do zapewnienia właściwej liczebności funkcjonariuszy w tych jednostkach, a także do odpowiedniego doboru funkcjonariuszy do

${ }^{21}$ Uchwała Sądu Najwyższego - Izba Administracyjna, Pracy i Ubezpieczeń Społecznych z dnia 4 lutego 1993 r., III AZP 38/92, Legalis nr 27972. 
poszczególnych komórek organizacyjnych tych jednostek Policji. Muszą zatem $\mathrm{z}$ jednej strony dostosować konkretne stanowisko służbowe do danego funkcjonariusza, w szczególności do jego kwalifikacji zawodowych, doświadczenia $i$ innych jego przymiotów. $Z$ drugiej jednak strony zobowiązani są do podejmowania takich czynności, w tym kadrowych, które leżąc w ich kompetencji, stanowić będą o działaniu ukierunkowanym na zapewnienie (na zagwarantowaniu) pełnej realizacji zadań tych jednostek, tj. utrzymania stanu bezpieczeństwa i porządku publicznego. Obowiązki te skutkują tym, iż podejmując decyzję kadrową w odniesieniu do konkretnego policjanta, muszą wziąć pod uwagę partykularny interes funkcjonariusza, jeśli jest on jednocześnie zbieżny z interesem służby (dobrem służby). Nie może być mowy o prymacie interesu policjanta, gdy jego zatrudnienie nie przyczynia się do realizacji ustawowych zadań Policji, albo gdy znacznie utrudnia lub wręcz uniemożliwia wykonywanie tych zadań przez określoną komórkę organizacyjną lub jednostkę Policji. Z kolei predyspozycje, doświadczenie czy kwalifikacje zawodowe funkcjonariusza są jedynie warunkiem koniecznym do dalszego zatrudnienia go na określonym stanowisku służbowym, co nie oznacza, że są one warunkiem wystarczającym. Nie mogą bowiem jeszcze determinować do dalszego zatrudnienia policjanta. Warunkiem tym jest realna potrzeba służby, która pozwala albo na pełnienie służby przez danego policjanta na dotychczasowym stanowisku służbowym, albo na innym, jeśli w ocenie jego przełożonego konieczne jest uzupełnienie takiego stanowiska policjantem o odpowiednich kwalifikacjach i doświadczeniu, a także uzasadnione podstawy do przyjęcia, że będzie on dawał gwarancję prawidłowej realizacji nałożonych na niego obowiązków służbowych. Nie może być wobec tego mowy jedynie o subiektywnym przekonaniu samego policjanta o jego przydatności do dalszego pełnienia służby na konkretnym stanowisku służbowym czy o jego kwalifikacjach i doświadczeniu do wykonywania określonych zadań.

Jak już wcześniej zaznaczono, ocena w tym aspekcie należy do właściwego przełożonego, który powinien dążyć do optymalnego wykorzystania posiadanego zasobu kadrowego podległej mu jednostki Policji. Każda komórka organizacyjna jednostki Policji stanowi bowiem pewien zorganizowany zespół osobowy, w którym każdy funkcjonariusz musi być nieodzownym elementem zapewniającym prawidłowe jej funkcjonowanie. Tylko w ten sposób może zostać osiągnięta pełna zdolność operacyjna poszczególnych komórek organizacyjnych, a tym samym jednostki Policji do podjęcia i wykonania określonych zadań. Przełożony musi zatem dokonać oceny przymiotów, któ- 
rymi winien legitymować się każdy funkcjonariusz, ale przez pryzmat ich przydatności dla określonego zespołu osobowego, bowiem muszą one być przydatne i pozwalać na realizację stawianych przed tą komórką zadań.

Oczywiście wskazane elementy nie konkretyzują przesłanki zawartej w art. 41 ust. 2 pkt 4 ustawy o Policji, bo jest nią wyłącznie nabycie przez policjanta prawa do emerytury z tytułu osiągnięcia 30 lat wysługi emerytalnej. Niemniej ocena przydatności policjanta, który nabył prawo do emerytury z tytułu osiągnięcia 30 lat wysługi emerytalnej, do dalszego pełnienia służby stanowi uzasadnienie, a jednocześnie wytycza granice uznania administracyjnego dla podjętej przez przełożonego właściwego w sprawach osobowych decyzji opartej na fakultatywnej podstawie zwolnienia ze służby w Policji. Nie może budzić wątpliwości, że nie sposób kauzalnie wyliczyć wszystkich elementów, które mogą stanowić uzasadnienie dla decyzji o zwolnieniu ze służby na wymienionej podstawie. Nie jest również możliwe precyzyjne wskazanie kryterium determinującego do podjęcia takiej decyzji przez przełożonego właściwego w sprawach osobowych, które byłoby obiektywnie mierzalne i umożliwiałoby automatyczną identyfikację przyczyny (lub przyczyn), z powodu której (których) przełożony właściwy w sprawach osobowych dokonał wyboru określonego funkcjonariusza i zwolnił go zgodnie z podstawą zamieszczoną w art. 41 ust. 2 pkt 4 ustawy o Policji. Służba w Policji nie miała i nadal nie ma charakteru wymiernego, bo zadań, które realizuje ta formacja, nie można ująć w proste ramy. Nie da się stworzyć algorytmu, według którego możliwe byłoby posługiwanie się elementami wartościującymi w sposób zero-jedynkowy, pozwalającymi na dokonanie oceny wszystkich funkcjonariuszy tymi samymi kryteriami. Inne są bowiem zadania indywidualne policjanta, które realizuje samodzielnie, zaś inne te, które realizuje jako członek określonego zespołu. Inne są również zadania poszczególnych komórek organizacyjnych, a także jednostek Policji. Ocena przełożonego jest z kolei sumą ocen cząstkowych, na którą składa się nie tylko ocena dotychczasowej przydatności danego funkcjonariusza, ale także ocena jego dalszej przydatności do służby, w tym w szczególności w kontekście możliwości dalszego wykorzystania jego potencjału, kwalifikacji, doświadczenia oraz przymiotów w środowisku, w którym miałby on nadal pełnić służbę, czyli jako członka określonego zespołu osobowego w określonej komórce organizacyjnej jednostki Policji, w której miałby realizować nie tylko indywidualne zadania, ale zadania zespołu. Te, co jeszcze raz należy podkreślić, mają charakter stricte ocenny i wynikają z obserwacji funkcjonariusza. 
Staż służby może z kolei powodować, iż przymioty danego funkcjonariusza, które były uprzednio wykorzystywane w służbie, tj. pełna dyspozycyjność, zdolność do szybkiego i sprawnego przystosowania się do nowych potrzeb służby, do przekwalifikowania się, nabywania nowych umiejętności etc., uległy już znacznemu ograniczeniu lub funkcjonariusz bezpowrotnie je utracił. Umiejętności, którymi obecnie dysponuje funkcjonariusz, mogą nie być już przydatne do realizacji zadan Policji albo wykorzystywane przez tę formację $\mathrm{w}$ takim zakresie jak w przeszłości, w szczególności z uwagi na zmiany w przepisach prawa czy postęp technologiczny ${ }^{22}$. Przełożony właściwy w sprawach osobowych musi natomiast wkomponować danego funkcjonariusza w przyjętą koncepcję funkcjonowania danej komórki organizacyjnej, a tym samym do całej jednostki, którą kieruje. Odwrócenie tego mechanizmu skutkowałoby tym, iż nadrzędną wartością byłoby utrzymanie zatrudnienia funkcjonariusza, nawet kosztem obniżenia zdolności danej komórki lub jednostki Policji do realizacji jej zadań. Tym samym interes służby (interes społeczny), rozumiany jako zobowiązanie Policji do zapewnienia i utrzymania bezpieczeństwa i porządku publicznego, zostałby zepchnięty na dalszy plan.

Jak słusznie wskazuje NSA w wyroku z dnia 27 sierpnia 2013 r., I OSK $1403 / 12^{23}$ :

ustawodawca dopuszcza możliwość, że część funkcjonariuszy posiadających 30-letnią wysługę emerytalną będzie dalej wykonywać swoją służbę, natomiast inni zostaną zwolnieni ze służby i przejdą na emeryturę. To przełożony funkcjonariusza może zadecydować, biorąc pod uwagę wszelkie okoliczności sprawy, czy skorzystać z przysługującego prawa, czy też z uwagi na indywidualne cechy funkcjonariusza, pomimo przewidzianej wyraźnie prawem możliwości przejścia na emeryturę - pozostawić funkcjonariusza w służbie ${ }^{24}$.

\footnotetext{
${ }^{22}$ Jak zaznacza A. Korcz-Maciejko, przepis art. 41 ust. 2 pkt 4 ustawy o Policji daje względną swobodę przełożonemu właściwemu w sprawach osobowych w odmładzaniu zasobów kadrowych, gdy funkcjonariusze, którzy dotychczas pełnili służbę, nabyli pełne uprawnienia emerytalne (A. KorCZ-MACIEJKo, Postępowanie w sprawach zwolnienia ze slużby w Policji, [w:] W. MACIEJKO, A. KorCZ-MACIEJKO, Postępowanie $w$ sprawach osobowych $w$ Policji, Wrocław: Gaskor 2010, s. 309). Z twierdzeniem tym należy się zgodzić i jednocześnie uzupełnić, bowiem zazwyczaj osiągnięty wiek jest przyczyną obniżenia przydatności funkcjonariusza do służby. Może on mieć zatem bezpośredni wpływ na zdolność osoby fizycznej do bycia funkcjonariuszem (por. M. WIECZOREK, Charakter prawny, s. 263).

${ }^{23}$ Legalis nr 1924893.

${ }^{24} \mathrm{~W}$ tym samym tonie wyrok Wojewódzkiego Sądu Administracyjnego w Warszawie z dnia 24 lipca 2018 r., II SA/Wa 2129/17, Legalis nr 2301042.
} 
Przyznanie prymatu dobru prawnemu, jakim jest interes służby, przed partykularnym interesem jednostki wymaga zatem zrozumienia specyfiki tej służby, a ta zorientowana jest na efektywną realizację ustawowych zadań Policji, a także szczególnych i charakterystycznych elementów właściwych dla poszczególnych komórek organizacyjnych i jednostek Policji, zadań, które mają zostać przekazane do realizacji poszczególnym funkcjonariuszom, jak również koncepcji i kierunków polityki kadrowej prowadzonej przez właściwego przełożonego, a jednocześnie kierownika danej jednostki Policji. Realizacja tych zadań oraz urzeczywistnianie tych celów zmierza do realizacji i urzeczywistnienia zadań i celów wskazanych w art. 1 ustawy o Policji. Tym samym uwzględnienie interesu społecznego i słusznego interesu strony nie w każdym przypadku oznaczać będzie zrównoważenie tych dóbr. Nie można bowiem uczynić zarzutu przełożonemu właściwemu w sprawach osobowych, że przedłożył interes służby ponad indywidualny interes policjanta. Interes służby uzasadnia bowiem pozostawienie w służbie wyłącznie tych policjantów, którzy w ocenie właściwego przełożonego będą zdolni do prawidłowej realizacji nałożonych na nich zadań, zadań komórki organizacyjnej, jednostki Policji, a w szerszym aspekcie - Policji ${ }^{25}$.

\section{WNIOSKI}

Służba w Policji to szczególny rodzaj służby publicznej. Zadania, do których wykonywania została zobligowana ta formacja, wymaga zapewnienia rzeczywistych ich wykonawców. Są nimi funkcjonariusze. W pragmatyce służbowej przewidziano natomiast szereg instrumentów prawnych, które służyć mają stworzeniu optymalnych warunków do realizacji tych zadań. Jednym $\mathrm{z}$ nich jest konstrukcja stosunku służbowego, jako więzi prawnej o stricte administracyjnoprawnym charakterze. Zamknięty katalog podstaw zwolnienia ze służby jest natomiast tym elementem, który pozwala na stwierdzenie, iż stosunek służbowy charakteryzuje się większą trwałością i stabilnością, bo wyklucza możliwość zwolnienia funkcjonariusza na innej podstawie niż te, które zamieszczone są w pragmatyce służbowej.

Jedną z podstaw fakultatywnego zwolnienia policjanta ze służby jest art. 41 ust. 2 pkt 4 ustawy o Policji, który umożliwia rozwiązanie stosunku służ-

${ }^{25}$ Wyrok Wojewódzkiego Sądu Administracyjnego w Lublinie z dnia 22 stycznia 2009 r., III SA/Lu 487/08, Legalis nr 244885. Porównaj z wyrokiem Wojewódzkiego Sądu Administracyjnego w Warszawie z dnia 9 października 2018 r., II SA/Wa 358/18, Legalis nr 2299615. 
bowego z policjantem, który nabył prawo do emerytury z tytułu osiągnięcia 30 lat wysługi emerytalnej. Jest to jedyna przesłanka, która wymaga dowiedzenia $\mathrm{w}$ postępowaniu administracyjnym wszczętym na wymienionej podstawie. Ustalenie, że zmaterializowała się przesłanka do fakultatywnego zwolnienia policjanta ze służby jest warunkiem koniecznym lecz niewystarczającym do rozwiązania z nim stosunku służbowego. Taka decyzja byłaby dowolna i arbitralna. Decyzja w kwestii zwolnienia na którejkolwiek z podstaw wskazanych w art. 41 ust. 2 ustawy o Policji ma charakter uznaniowy, a zatem jest ograniczona treścią art. 7 k.p.a. Organ musi wobec tego wykazać, że zwalniając policjanta ze służby uwzględnił zarówno interes społeczny, jak i słuszny interes strony. Nie oznacza to tym samym, iż w każdym przypadku możliwe będzie zrównoważenie tych dóbr, zwłaszcza w sytuacji oczywistej kolizji pomiędzy nimi. Wówczas to na organie administracyjnym ciąży obowiązek wykazania, któremu z tych dóbr dał prymat. Zaznaczyć przy tym należy, że interes społeczny w tym przypadku równoznaczny jest z pojęciem takim, jak interes służby lub jej dobro. Formacja, jaką jest Policja, musi bowiem realizować wytyczone jej zadania, a samo zatrudnienie policjantów winno służyć temu celowi. Tym samym zatrudnienie funkcjonariuszy stanowi środek do celu, jakim jest zagwarantowanie faktycznych i rzeczywistych wykonawców tych zadan. Jeśli zatrudnienie nie spełnia tego celu, to w interesie służby i dla jej dobra konieczne jest rozwiązanie stosunku służbowego. Instrumentem, który umożliwia podjęcie takiego działania przez przełożonego właściwego w sprawach osobowych, jest właśnie podstawa zwolnienia zawarta w art. 41 ust. 2 pkt 4 ustawy o Policji.

\section{BIBLIOGRAFIA}

\section{ŹRÓDŁA PRAWA}

Konstytucja Rzeczypospolitej z dnia 2 kwietnia 1997 r., Dz.U. z 1997 r., Nr 78, poz. 483 z późn. zm.

Ustawa z dnia 18 lutego 1994 r. o zaopatrzeniu emerytalnym funkcjonariuszy Policji, Agencji Bezpieczeństwa Wewnętrznego, Agencji Wywiadu, Służby Kontrwywiadu Wojskowego, Służby Wywiadu Wojskowego, Centralnego Biura Antykorupcyjnego, Straży Granicznej, Straży Marszałkowskiej, Służby Ochrony Państwa, Państwowej Straży Pożarnej, Służby Celno-Skarbowej i Służby Więziennej oraz ich rodzin, Dz.U. z 2020 r., poz. 723.

Ustawa z dnia 6 kwietnia 1990 r. o Policji, Dz.U. z 2020 r., poz. 360 z późn. zm.

Ustawa z dnia 26 czerwca 1974 r. - Kodeks pracy, Dz.U. z 2020 r., poz. 1320 z późn. zm.

Ustawa z dnia 14 czerwca 1960 r. - Kodeks postępowania administracyjnego, Dz.U. z 2021 r., poz. $735 \mathrm{z}$ późn. zm. 


\section{ORZECZNICTWO}

Uchwała Sądu Najwyższego - Izba Administracyjna, Pracy i Ubezpieczeń Społecznych z dnia 4 lutego 1993 r., III AZP 38/92, Legalis nr 27972.

Uchwała Sądu Najwyższego - Izba Administracyjna, Pracy i Ubezpieczeń Społecznych z dnia 5 grudnia 1991 r., I PZP 60/91, Legalis nr 27539.

Wyrok Sądu Najwyższego z dnia 1 października 1977 r., I CR 530/77, niepubl.

Wyrok Naczelnego Sądu Administracyjnego z dnia 26 października 2016 r., II OSK 132/15, Legalis nr 1554129.

Wyrok Naczelnego Sądu Administracyjnego z dnia 27 sierpnia 2013 r., I OSK 1403/12, Legalis nr 1924893.

Wyrok Naczelnego Sądu Administracyjnego z dnia 9 maja 2012 r., I OSK 1840/11, Legalis nr 778645 .

Wyrok Naczelnego Sądu Administracyjnego z dnia 16 października 2009 r., I OSK 174/09, Legalis $\mathrm{nr} 212998$.

Wyrok Wojewódzkiego Sądu Administracyjnego w Warszawie z dnia 11 grudnia 2018 r., II SA/Wa 2133/17, Legalis nr 1974446.

Wyrok Wojewódzkiego Sądu Administracyjnego w Warszawie z dnia 9 października 2018 r., II SA/Wa 358/18, Legalis nr 2299615.

Wyrok Wojewódzkiego Sądu Administracyjnego w Warszawie z dnia 10 sierpnia 2018 r., II SA/Wa 2131/17, Legalis nr 2300580.

Wyrok Wojewódzkiego Sądu Administracyjnego w Warszawie z dnia 24 lipca 2018 r., II SA/Wa 2129/17, Legalis nr 2301042.

Wyrok Wojewódzkiego Sądu Administracyjnego w Poznaniu z dnia 18 stycznia 2018 r., IV SA/Po 960/17, Legalis nr 1741128.

Wyrok Wojewódzkiego Sądu Administracyjnego w Warszawie z dnia 28 czerwca 2010 r., II SA/Wa 401/10, Legalis nr 253011.

Wyrok Wojewódzkiego Sądu Administracyjnego w Warszawie z dnia 10 lutego 2009 r., II SA/Wa 1264/08, Legalis nr 183469.

Wyrok Wojewódzkiego Sądu Administracyjnego w Lublinie z dnia 22 stycznia 2009 r., III SA/Lu 487/08, Legalis nr 244885.

\section{LITERATURA}

GACEK Paweł: Nawiązanie stosunku służbowego z funkcjonariuszem Policji, „Administracja Teoria Dydaktyka Praktyka” 2011, nr 2 (23), s. 68-93.

GACEK Paweł: Odwołanie od rozkazu personalnego, „Przegląd Policyjny” 2016, nr 3 (123), s. 80-98.

GACEK Paweł: Opinia organizacji zakładowej związku zawodowego policjantów w sprawie zwolnienia ze służby w Policji (art. 43 ust. 3 ustawy o Policji), „Policja. Kwartalnik Kadry Kierowniczej Policji” 2018, nr 2, s. 26-37.

GACEK Paweł: Orzeczenie o trwałej niezdolności do służby jako podstawa obligatoryjnego zwolnienia ze służby w Policji, „Przegląd Policyjny” 2020, nr 2 (138), s. 121-146.

GACEK Paweł: Zwolnienie ze służby w Policji na podstawie art. 41 ust. 2 pkt 5 ustawy o Policji a prawo policjanta do nagrody rocznej, „Roczniki Nauk Prawnych” 29(2019), nr 4, s. 201-221. 
GaceK Paweł: Zwolnienie ze służby w Policji w związku ze złożonym przez policjanta pisemnym zgłoszeniem o wystąpieniu z niej na podstawie art. 41 ust. 3 ustawy z dnia 6 kwietnia 1990 o Policji, „Przegląd Policyjny” 2018, nr 2 (130), s. 63-91.

GACEK Paweł: Zmiana stadium postępowania karnego jako podstawa do zwolnienia policjanta ze służby w Policji ze względu na „ważny interes służby”, „Przegląd Policyjny” 2017, nr 4 (128), s. 70-99.

KotowsKi Wojciech: Ustawa o Policji. Komentarz, Warszawa: Wolters Kluwer 2008.

Korus PaweŁ: Komentarz do art. 2, [w:] Kodeks pracy. Komentarz, red. Arkadiusz Sobczyk, Legalis, teza 5 .

KuCZYŃSKi Tadeusz, MAZurCZAK-JASIŃSKA Eliza, STElinA Jakub: Stosunek służbowy, [w:] System prawa administracyjnego, t. XI, red. Roman Hauser, Zygmunt Niewiadomski, Andrzej Wróbel, Warszawa: C.H. Beck 2011.

KUCZYŃSKI Tadeusz: Wybrane problemy orzecznictwa sądowoadministracyjnego w sprawach z zakresu stosunków służbowych, „Zeszyty Naukowe Sądownictwa Administracyjnego" 2010, nr 5-6 (32-33), s. 249-266.

KorCZ-MACIEJKo Aneta: Postępowanie w sprawach zwolnienia ze służby w Policji, [w:] Wojciech MaciejKo, Aneta KorCZ-Maciejko, Postępowanie w sprawach osobowych w Policji, Wrocław: Gaskor 2010, s. 279-343.

MichaŁeK Aneta: Komentarz do art. 28, [w:] Łukasz Czebotar, Zuzanna GĄDZIK, Aneta Łyżwa, Aneta Michalek, Anna Świerczewska-Gąsiorowska, Mirosław ToKarski, Ustawa o Policji. Komentarz, Warszawa: Wolters Kluwer 2015, s. 366-368.

NowIKOwsKa Monika: Komentarz do art. 41, [w:] Ustawa o Policji. Komentarz, red. Katarzyna Chałubińska-Jentkiewicz, Justyna Kurek, Legalis, teza 14.

OpALIŃSKI Bartłomiej: Komentarz do art. 41, [w:] Bartłomiej OpALIŃSKI, Maciej RoGALSKI, Przemysław Szustakiewicz, Ustawa o Policji. Komentarz, Legalis, teza 2.

SzuSTAKIEwICz Przemysław: Stosunki służbowe funkcjonariuszy służb mundurowych i żołnierzy zawodowych jako sprawa administracyjna, Warszawa: Difin S.A. 2012.

TANiewska Maria: Stosunek służbowy funkcjonariuszy Policji, Urzędu Ochrony Państwa i Straży Granicznej, [w:] Prawo policyjne. Komentarz, red. Stanisław Sagan, Katowice: POLBOD 1992, s. 68-78.

WIECZOREK Mariusz: Charakter prawny stosunków służbowych funkcjonariuszy służb mundurowych, Toruń: Wydawnictwo Adam Marszałek 2017.

ZIELIŃSKI Tadeusz: Stosunek prawa pracy do prawa administracyjnego, Warszawa: Wydawnictwo PWN 1977.

\section{ZWOLNIENIE ZE SŁUŻBY W POLICJI \\ NA PODSTAWIE ART. 41 UST. 2 PKT 4 USTAWY O POLICJI \\ W ZWIAZZKU Z NABYCIEM PRZEZ FUNKCJONARIUSZA PRAWA DO EMERYTURY}

\section{Streszczenie}

Niniejszy artykuł został w całości poświęcony problematyce zwolnienia ze służby na podstawie art. 41 ust. 2 pkt 4 ustawy o Policji. Przepis ten warunkuje zwolnienie policjanta od faktu nabycia przez niego prawa do emerytury z tytułu osiągnięcia 30 lat wysługi emerytalnej. Omó- 
wiono zatem przesłankę umożliwiającą zastosowanie tej podstawy zwolnienia ze służby. Decyzja w tym zakresie ma jednak charakter uznaniowy. Wymaga zatem uwzględnienia zarówno interesu społecznego, jak i słusznego interesu strony. Wskazano wobec tego na granicę uznania administracyjnego uzasadniającego podjęcie decyzji o zwolnieniu na tej podstawie prawnej.

Słowa kluczowe: Policja; policjant; zwolnienie ze służby w Policji; decyzja administracyjna

\section{DISMISSAL FROM SERVICE IN THE POLICE \\ UNDER ART. 41 SECTION 2 POINT 4 OF THE ACT ON THE POLICE IN RELATION TO THE ACQUISITION OF PENSION THE RIGHTS}

\section{Summary}

The article is entirely devoted to the issues related to the dismission from the service in the Police based on the Art. 41 (2) (4) Act on the Police. This provision conditions the dismission of a police officer from the fact of acquiring the right to a pension due to reaching 30 years of retirement service. Therefore, the prerequisite for the application of this legal ground for dismission from service was discussed. However, the decision in this respect is of a discretionary nature. Thus, it requires taking into account both the public interest and the legitimate interest of the party. Therefore, the limit of administrative discretion justifying the decision to dismiss on this legal ground was indicated.

Keywords: Police; Police officer; dismissal from service in the Police; administrative decision 